Journal of Management and Development Studies

Volume: 30 , Issue $1,14-23$

(C) 2021 Nepal Administrative Staff College

Article Link: https://doi.org/10.3126/jmds.v30i1.36347

https://www.nasc.org.np/journals/all

ISSN 2392-4896 online/ ISSN 2392-4888 print

\title{
Impact of foreign exchange reserve on economic growth in Nepal
}

\section{Raghu Raj Kaphle}

raghukaphle123@gmail.com

\begin{abstract}
This study primarily focuses on the analysis of the contributions of foreign exchange reserve to the economic growth of Nepal by using time series data obtained from the year 1975 to 2018 A.D. In order to assess a relationship between these variables, statistical procedure of unit root test, cointegration and Vector Error Correction Model (VECM) are applied. In addition to the t-statistics, Wald-test for joint significance of coefficients is applied and VECM is performed for testing the impact of the past values of foreign exchange on dependent variables which show the nation's economic growth. Based on the statistical outcome; Johansen cointegration test indicates the existence of the long-run relationship among variables. The Vector Error Correction outcome and Wald statistics confirm that the past values of foreign exchange have a positive contribution to the economic growth; and foreign exchange reserve has contributed to the economic growth of Nepal.
\end{abstract}

Keywords: Foreign exchange reserve, economic growth, vector error correction mechanism

\section{Introduction}

Developing countries need more foreign exchange to fulfil their developmental needs, but they have limited access to it. To earn foreign exchange, they get involved in international trade, work for better and stable investment opportunity and manage internal financial stability (McKinnon, 1973; World Bank [WB], 1997). It is widely accepted that at the initial stage of development, each developing country needs to import raw materials, construction materials and tools, heavy equipment, advanced technology and expert services that may be highly expensive. To fulfill this demand, they try to reserve more foreign currencies (Krugman, 1984). In the least developed countries (LDCs), the imported capital goods are one of the determinants of capital accumulation (Ahmad, 1989). Export is the oldest source of foreign exchange earnings. Foreign direct investment (FDI) is also a source of foreign exchange which may come along with external technology and knowledge. In addition, foreign assistance, tourism and remittance are other major sources of foreign exchange earnings. These days, remittance is also identified as the growing source of 
foreign exchange earnings. Developing countries need more foreign exchange reserve which could be used as capital to address development and welfare demands of the nation (Kargbo, 2012).

Economic growth is the only appropriate means of improving the living standard of people (Rodrik, 2008). Foreign exchange can be used as productive capital to improve economic activities not only to help earn foreign exchange but also to help achieve higher economic growth. There has been a strong unidirectional causality from foreign aid to GDP. This helps to conclude that foreign aid has a significant contribution to economic growth (Regmi, 2009). To enhance the economic growth of developing countries, foreign aid is an important source of finance (Bhattarai, 2009) but poor countries are unable to reach the stage of take off because of inadequate aid support (Dowling \& Hiemenz, 1983). Foreign aid, if provided and recieved, helps the developing countries to fill the foreign currency gap and low saving gap (Papanek, 1973). There is bi-directional causality between variables, gross domestic product, export and foreign direct investment (Ahmadi \& Ghanbarzadeh, 2011; Ekanayake, 1999).

Inflow of foreign capitals in terms of foreign direct investment produce long-term and positive relation to the economic growth of a nation (Ray, 2012) and the relationship is for a long time and bi-directional as well (Majagaiya, 2010). Worker remittances, at individual level, play an important role to start new businesses, to create small capitals for investment and learn new skills; and at the national level, that would be helpful to formulate a capital, which would help to promote national economic growth (Giuliano \& Arranz, 2009). Remittance is a more sustainable source of foreign currency for the developing countries than other capital inflows (Lubambu, 2014). Earning of foreign currency from export, tourism and remittance is positively related to the nation's economic growth (Dhungel, 2012).

Nepal is a developing country with poor infrastructure (Ministry of Finance [MoF], 2014); thus the country needs to import raw materials and advanced technology which demands more foreign exchange. There are various means of gaining foreign exchange which are in practice in Nepal. Nepal has a huge potential to achieve foreign exchange from worker remittances, tourism, exports, FDIs, foreign aids, etc. Research shows that foreign exchange helps achieve higher economic growth, however Nepal is unable to achieve higher economic growth in spite of receiving foreign exchange through different sources. This fact encourages the researcher to test the relation between foreign exchange reserve and economic growth. The main objective of this article is to identify the impact of foreign exchange earnings on the economic growth of Nepal and to explore the causal relationship between variables for policy recommendation on effective utilization of the foreign exchange.

\section{Conceptualizing foreign exchange reserve}

Capital inflow into the developing countries is necessary for the purpose of investment, trade or business production. For the developing economies, capital inflow is used to increase investment and to achieve higher economic growth (Chigbu \& Promise, 2015). Countries like to reserve foreign currency in US Dollars not only to facilitate international trade, but also to promote economic growth regardless of the size and development level of a country (Azar \& Aboukhodor, 2017). Furthermore, increased foreign exchange reserve reduces cost of liquidity risk (Fukuda \& Kon, 2008). 
A few remarkable empirical studies are carried out to observe the relation between economic growth and foreign exchange reserve. Kashif et al., (2017) concluded that economic growth has both short-run and long-run relationship with the foreign exchange reserve. The foreign exchange reserve has a positive impact on economic growth, but high economic growth does not support to increase foreign exchange (Kruskovic \& Maricic, 2015). Furthermore, the less developed countries set the goal to achieve more foreign currency to achieve higher economic growth. Accumulation of foreign exchange reserve contributes to the economic growth of developing economies by increasing both the investment/GDP ratio and the capital productivity (Weintraub, 1965; Polterovich \& Popov, 2003). Foreign exchange is an external stock of assets that is normally managed by central monetary authority of a nation to influence exchange rate and to stabilize the economy to achieve broader economic objectives (International Monetary Fund [IMF], 2000). When foreign reserve increases due to increase in the export of goods and services that would be better for the economy to generate more job and strengthen the internal economy as well (Dooley et al., 2003). Developing countries should try to increase foreign direct investment, but this is not easy to achieve. They should try to generate internal resources by checking capital flight and encourage external development assistance. Achievement of higher economic growth utilizing foreign exchange reserve is a time-consuming process. This requires a massive amount of funds and deep policy reform. So, mobilization of foreign exchange for higher growth is not free from debate (Sebastian, 1990).

There is a debate about the need of holding large foreign currency reserve. Some critics point out that holding of foreign currency may cause many types of risks and cost implication too which should also be taken into consideration (Aizenman \& Marion, 2003). In this regard, Ben-Bassat and Gottlieb (1992) claim that there is a negative relationship between the demand for foreign reserve and the opportunity cost of holding these reserves. Foreign reserve accumulation had negative impact on the economic growth of Nigeria (Nathaniel \& Oladiran, 2018). Lin (2011) concludes that foreign reserve unilaterally causes economic growth only in the emerging countries but not in the advanced countries. Also, it is recommended that developing countries should spend foreign exchange cautiously as large and prolonged reserve accumulation can create inflation, monetary imbalances, overheat credit and distort the banking system (Mohanty \& Turner, 2006). Developing countries have limited absorptive capacity for foreign resources because their financial markets are not well developed and sustained. Therefore, only accumulation and increase in the foreign exchange reserve will increase consumption of foreign goods and thereby promote high imports (Prasad, 2007).

Foreign reserve mainly provides these benefits: exchange rate stability, mercantilist export promotion and resolve financial crisis. During financial crisis East Asian countries focused on producing more exportable goods and services which helped them to increase volume of foreign exchange after economic crisis. However, high reserve of foreign currency demanded better utilization of resources to maximize risk-adjusted returns (Park \& Estrada, 2009). Developing countries are aggressively increasing the volume of foreign exchange earning basically after the realization of East Asian crisis of the year 1997 and those reserves are used for external payment purpose (Prabheesh et al., 2007). The earning capacity and optimum reserve volume are based on economic size, current account vulnerability, exchange rate flexibility and opportunity cost of a nation. So, nation should determine the volume of foreign exchange based on its utilization 
capacity (Gould, 2003). If the investment and business climate is poor, capital is likely to fly abroad. So, foreign capital accumulation needs a favourable investment environment in the country (Polterovich \& Popov, 2003).

\section{Foreign exchange reserve in Nepal}

Nepal has immense development needs which are possible only through high economic growth rate. Nepal experienced minimum economic growth prior to 1980s, but enjoyed some changes in the early 1980 s with the introduction of liberal financial sector and open international trade. The liberal policy could not contribute for a long time and average growth rate for the last four decades remained around four percent (MoF, 2014). Nepal needs more resources to accelerate economic growth and that demands hard currency which can be achieved through different sources. To achieve more foreign exchange, Nepal needs to promote export, tourism industry, increase earning from foreign employment, attract direct foreign investments, grants and aids. High reserve of foreign currency can be invested in industries, manufacturing businesses or trades and other productive and profitable investment activities to achieve higher growth rate. The status of economic growth rate and foreign currency reserve is presented in the table-1 below.

Table 1: GDP growth of Nepal

\begin{tabular}{lllllllllll}
\hline Year & 1975 & 1980 & 1985 & 1990 & 1995 & 2000 & 2005 & 2010 & 2015 & 2018 \\
GDP Growth Rate & 1.5 & -2.3 & 6.1 & 4.6 & 3.5 & 6.2 & 3.5 & 4.8 & 3.3 & 6.8 \\
\hline
\end{tabular}

Source: World Development Index, 2018.

Table 1 above depicts that the economic growth rate was 1.5 percent in 1975 A.D. and it increased to 6 percent in 2000 A.D. and then reached up to 6.8 percent in 2018 A.D. However, as seen in the data given above, the growth rate in some five-year periods has noticeably decreased and in some five-year periods the growth rate has been negative too. These data indicate that the growth rate is not stable in the country. At the time of political stability, together with the private sectors, the government of Nepal invested in the development activities especially in infrastructure, social development and agricultural sectors and during that time economic growth was relatively higher. During the political unrest of about ten years, Nepal suffered from political instability and internal conflict. People's security was in higher priority and economic development was in lower priority, the trend of foreign exchange reserve in Nepal as one of the major contributors to economic growth was continuing. The trend of foreign exchange reserve of every five-year period from 1976 to 2015 is presented in the Table 2 below.

Table 2: Reserve of foreign currency (US\$ million)

\begin{tabular}{|c|c|c|c|c|c|c|c|c|c|c|c|c|c|c|c|c|c|c|}
\hline \multirow{2}{*}{ Country } & \multicolumn{2}{|c|}{1976} & \multicolumn{2}{|c|}{1980} & \multicolumn{2}{|c|}{1985} & \multicolumn{2}{|c|}{1990} & \multicolumn{2}{|c|}{1995} & \multicolumn{2}{|c|}{2000} & \multicolumn{2}{|c|}{2005} & \multicolumn{2}{|c|}{2010} & \multicolumn{2}{|l|}{2015} \\
\hline & $M$ & TR & $M$ & TR & $M$ & TR & $M$ & TR & $M$ & TR & $M$ & TR & $M$ & TR & $M$ & TR & $M$ & TR \\
\hline Nepal & 8.8 & 145 & 7.8 & 272 & 2.2 & 105 & 5.0 & 354 & 4.7 & 646 & 6.5 & 987 & 6.7 & 1565 & 6.0 & 3003 & 12.5 & 8145 \\
\hline
\end{tabular}

Source: World Development Index, 2018. Note: $\mathrm{M}=$ Total month of imports \& TR= Total reserve including gold

Table 2 above shows that in terms of finance import and foreign exchange reserve, it can be said that the condition of Nepal is satisfactory, but the contribution of foreign exchange reserve to national GDP growth is still a question of examination. Nepal adopted liberal economic policies 
one after another and exercised the concept of open economy but major macroeconomic indicators were found weak including the nation's economic growth. This piece of evidence has encouraged the researcher to explore the fact how far the foreign currency reserve is contributing to the country's economic growth. The contribution of foreign exchange to a country's economic growth has remained a matter of debate for a long time. The major question is: Does the growing foreign exchange earning contribute to achieve higher economic growth? The aim of this study is to measure the contribution of foreign exchange earnings to the economic growth of Nepal.

\section{Methodology}

This study used the five years' time series data from the year 1975 to 2018 A.D. In this study gross domestic product (GDP) of Nepal is used as a proxy of the economic growth. Foreign exchange reserve in the bank and gross capital formation are the variables of interest in this study. Foreign exchange reserve includes earning from export, earning from tourism, workers' remittance, foreign direct investment and foreign assistance including foreign debts. Foreign exchange reserve as a percentage of GDP is taken to analyze the impact of all these variables on the economic growth. In this study, gross fixed capital formation (GFCF) is used as a control variable as it is one of the major determinants of growth and this variable is also taken as a percentage of GDP for analysis uniformity. The data in this study were obtained from Uprety (2017) and the Central Bureau of Statistics (2018). Remittance related data are incomplete in Nepal and the data series used by Uprety in his research was compatible to the data series published by the CBS of Nepal. All data were converted into real term by using the GDP deflator.

To examine the strength of causal relationship between GDP, foreign exchange reserve (FOREX) and GFCF, this study used vector error correction method (VECM) from vector autoregressive approach as a statistical tool (Engle \& Granger, 1987; Johansen, 1995). Akaike Information Criterion (AIC) was used to select appropriate number of lag length for analysis. Augmented Dickey Fuller (ADF) test was helpful in detecting unit-root in the series and for cointegration, Johansen test of cointegration was used (Dickey \& Fuller, 1979; Granger, 1988). Parallel to probability and t-statistics of regression coefficients, Wald-test for joint significance was the major determinant for testing coefficient to test whether or not they are different from zero (Engle, 1984). In addition to these statistical tests, residual diagnostic tests were also performed for the violation of classical linear regression model (CLRM) assumptions.

\section{Results}

In this study, lag three was taken for the analysis which was supported by Akaike Information Criterion (AIC) analysis. ADF statistics revealed that all three series used in this study were I(1) in level i.e. had unit roots in level series and were stationary that was I(0) in the first difference. As all variable time series were I(1), the Eigen value and Trace statistics were derived using Johansen's Cointegration Test to see the presence of long-run relationship among variables. Test statistics showed that there existed one long-run cointegration equation among variables. So, further analysis was required and was done with cointegration equation in regression model as VECM.

\section{Regression results}

As there was cointegration among variables 'vector error correction mechanism' of Vector Autoregressive (VAR) method was applied because a set of variables was found to have one or 
more co-integrating vectors. Then VECM was applied as a suitable estimation technique that could adjust both short-run changes in variables and deviations from equilibrium. Similarly, VAR and VECM models were found better than OLS to estimate causal relationship (Greenslade et al., 2002; Senhadji, 1998) because VECM model provides long-term association and short-term dynamics of the endogenous variables. Also, the advantage of using VECM is that the estimation of VAR with error correcting term has more efficient coefficient estimates (Lütkepohl \& Krätzig, 2004).

Here the parameters drawn from estimation of VECM are analyzed for the strength of causal relationship among the economic growth, foreign exchange reserve and other control variables. Three respective equations, each being dependent variable, were estimated with lag length equal to three, which was suggested by AIC criteria to obtain coefficient and other parameters.

Table 3: Vector error correction estimate

\begin{tabular}{llll}
\hline Dependent Variable & DLnGDP & DFOREX & DGFCF \\
\hline DLnGDP(-1) & $-0.535201(0.0082)$ & $4.232978(0.8737)$ & $36.995420(0.0135)$ \\
DLnGDP(-2) & $-0.630169(0.0014)$ & $15.378040(0.5417)$ & $10.370440(0.4409)$ \\
DLnGDP(-3) & $0.054049(0.7652)$ & $8.539805(0.7361)$ & $18.671440(0.1734)$ \\
DFOREX(-1) & $0.001374(0.4139)$ & $0.568381(0.0206)$ & $-0.051660(0.6793)$ \\
DFOREX(-2) & $0.005675(0.0017)$ & $-0.131564(0.5705)$ & $-0.051164(0.6785)$ \\
DFOREX(-3) & $0.000912(0.6241)$ & $0.134217(0.6067)$ & $-0.160275(0.2531)$ \\
DGFCF(-1) & $0.000120(0.9574)$ & $-0.200004(0.5255)$ & $-0.136741(0.4165)$ \\
DGFCF(-2) & $-0.001940(0.3866)$ & $-0.194371(0.5341)$ & $0.151984(0.3636)$ \\
DGFCF(-3) & $0.004023(0.0745)$ & $-0.715523(0.0257)$ & $0.186563(0.2595)$ \\
ECT(-1) & $0.036747(0.0028)$ & $1.220313(0.4446)$ & $-2.430591(0.0071)$ \\
CONSTANT & $0.081040(0.0001)$ & $-0.667300(0.7952)$ & $-2.174196(0.1202)$ \\
& & & \\
R-squared & 0.607083 & 0.441174 & 0.467825 \\
Adj R-squared & 0.471594 & 0.248476 & 0.284316 \\
DW & 2.099013 & 2.087671 & 1.723578 \\
F-stat, (prob) & $4.480691(0.0007)$ & $2.289452(0.0400)$ & $2.549335(0.0240)$ \\
\hline Note:Probaji & &
\end{tabular}

Note: Probabilities are in parenthesis.

Table 3 above shows that probability and sign of error correction coefficient depict the long-run relationship between GFCF and independent variables such as FOREX and GDP but test statistics related ECT estimated in two other equations rejects long-run relationship. About short-run association among variables, probability of two-lag foreign exchange reserve showed positive association with GDP and similarly probability of three-lag GFCF was found causing negative impact on current stocks of foreign exchange reserve. The rest of the coefficients showed that there was no significant relationship between lag series and dependent variables as none of the probability estimates corresponding to coefficient was below five percent level. Estimated outcomes show that foreign exchange reserve is not contributing to the GDP of the country in the long-run which 
is similar to the outcome that the major contributor to foreign exchange earnings is the foreign employment but the major part of the remittance is used for consumption purpose rather than production (Nepal Rastra Bank [NRB], 2016). However, there are FDI inflows and exports, but the share of both in foreign exchange reserve in Nepal is substantially low (NRB, 2019).

Residual diagnostic test for all three equations shows that there is no violation of CLRM assumption, so the coefficients estimated are robust. To validate VECM outcomes, further Wald test for joint significant of coefficients was conducted and most of the coefficients showed no relationship with dependent variables, and results are presented in Table 4 below.

Table 4: Wald test for joint significance of coefficients in VECM equations

\begin{tabular}{ll}
\hline Null Hypothesis & Wald-test F-stat (Prob.) \\
\hline LNGDP does not cause FOREX & $0.473444(0.9247)$ \\
FOREX does not cause LNGDP & $12.52549(0.0058)$ \\
FOREX does not cause GFCF & $1.519344(0.6778)$ \\
GFCF does not cause FOREX & $6.704681(0.0819)$ \\
GFCF does not cause LNGDP & $5.338493(0.1486)$ \\
LNGDP does not cause GFCF & $7.999192(0.0460)$ \\
\hline
\end{tabular}

Note: Probabilities are in parenthesis.

From the results presented in the Table 4 above, the test statistics and probability of foreign exchange reveal that FOREX is contributing to the growth in GDP as seen in the analysis period, however, test statistics also shows that there is no impact of GDP growth on increasing foreign exchange earnings for the same period. Similarly, test probability also reveals that the growth in GDP is contributing to the promotion of gross capital formation in economy in-between the analysis period. Probabilities from Wald-test reveals that there is no support for the causal relationship among rest of the variables taken in this analysis.

\section{Discussion}

This study examines the strength of long-run relationship between economic growth, foreign exchange reserve and GFCF. Results drawn in this study are quite similar to the impact of foreign exchange reserve in developing countries which are insignificant (Kashif et al., 2017; Regmi, 2009). The major question was whether growing foreign exchange earnings in the country is contributing to the economic growth in Nepal or not. Remittance remained as the major source of foreign exchange earning in Nepal which is taken as the sustainable source of foreign exchange in developing countries (Lubambu, 2014). Generally foreign exchange helps to formulate capital and contributes to the nation's economic growth (Giuliano \& Arranz, 2009) which has been reflected in this study too. It is found that foreign exchange supports the nation's economic growth but the impact of economic growth is not found significantly encouraging in attracting foreign exchange in the country and this has been evident in other studies and researches, too (Kruskovic \& Maricic, 2015).

For the period, from 2005 to 2015 A.D., the average contribution of industrial sector to GDP was about six percent in Nepal. The share of manufacturing production has been declining in the 
economy. FDI was comparatively lower and development assistance from other countries also declined. Tourism sector contributed significantly to the foreign exchange reserve but remittance remained as the major source of foreign exchange for a long time. During the study period, remittance was mainly used for consumption purpose and only around one percent was used for production related activities (NRB, 2016). These evidences also support and justify the results drawn from the analysis; however, in the short-run, some fluctuations also appeared in the country in terms of the economic growth.

\section{Conclusion}

Nepal introduced public-private-partnership policy, foreign employment policy, tourism policy, foreign investment and technology transfer act, and special economic zone act to attract more foreign exchange through different means to accelerate economic development activities. Results of VECM analysis show that foreign exchange reserve has significant impact on GDP which can be seen in the analysis period. Further, Wald test strengthened causal relationship between FOREX and GDP drawn from VECM. GDP was found to be influencing gross fixed capital formation in the economy which showed that the investment policy in the country created some expected results. However, different aspects of the relationship can be critically analysed in further research. The results of this study reveal that increase in foreign exchange reserve has positive impact on the nation's economic growth but the growth in GDP is unable to promote foreign exchange earnings in the country. Thus, it can be concluded that the current mechanism for promoting determinants of economic growth is not functioning as per the plan. So, the government needs to introduce effective policy mechanism for accelerating the determinants of growth such as foreign exchange reserve to achieve higher economic growth in the country.

\section{References}

Ahmad, S. (1989). Foreign exchange and economic development: The case of Bangladesh. The Bangladesh Development Studies, 17(3), 1-20. https://bit.ly/39BBejC

Ahmadi, R., \& Ghanbarzadeh, M. (2011). FDI, exports and economic growth: Evidence from MENA region. Middle-East Journal of Scientific Research, 10 (2), 174-182. https://bit.ly/3bP2NIQ

Aizenman, J., \& Marion, N. (2003). The high demand for international reserves in the Far East: What is going on? Journal of the Japanese and International Economies, 17(3), 370-400. https://bit.ly/2M0M9eE

Azar, S. A., \& Aboukhodor, W. (2017). Foreign exchange reserves and the macro-economy in the GCC countries. Accounting and Finance Research, 6(3), 72-87. https://doi.org/10.5430/afr.v6n3p72

Ben-Bassat, A., \& Gottlieb, D. (1992). On the effect of opportunity cost on international reserve holdings. The Review of Economics and Statistics, 74(2), 329-332. https://www.jstor.org/stable/2109666

Bhattarai, B. P. (2009). Foreign aid and growth in Nepal: An empirical analysis. The Journal of Developing Areas, 42(2), 283-302. https://doi.org/10.1353/jda.0.0026

Chigbu Ezeji, E., \& Promise, U. C. (2015). Impact of capital inflows on economic growth of developing countries. International Journal of Management Science and Business Administration, 1(7), 7-21. https:// doi.org/10.18775/ijmsba.1849-5664-5419.2014.17.1001

Dhungel, K. R. (2012). On the relationship between remittance and economic growth: Evidence from Nepal. South Asia Journal, 6, 52-67.

Dickey, D. A., \& Fuller, W. A. (1979). Distribution of the estimators for autoregressive time series with a unit root. Journal of the American Statistical Association, 74(366a), 427-431. https://bit.ly/2Lx195x

Dooley, M. P., Folkerts-Landau, D., \& Garber, P. (2003). An essay on the revived Bretton Woods System. National Bureau of Economic Research. https://bit.ly/3qskiCW 
Dowling, J. M., \& Heimenz, U. (1983). Aid, savings, and growth in the Asian region. Developing Economies, 21(1), 3-13. https://bit.ly/3nVniWE

economic growth in Nigeria. American Journal of Social Sciences, 6(2), 15-24. https://bit.ly/2Ne9B8O

Ekanayake, E. M. (1999). Exports and economic growth in Asian developing countries: Cointegration and error correction models. Journal of Economic Development, 24(2), 43-56. https://bit.ly/39Gcff4

Engle, R. F. (1984). Wald, likelihood ratio, and Lagrange multiplier tests in econometrics. Handbook of Econometrics, 2, 775-826. https://doi.org/10.1016/S1573-4412(84)02005-5

Engle, R. F., \& Granger, C. W. (1987). Co-integration and error correction: representation, estimation, and testing. Econometrica: journal of the Econometric Society, 55(2), 251-276. https://doi. $\operatorname{org} / 10.2307 / 1913236$

Fukuda, S. I., \& Kon, Y (2008). Macroeconomic impacts of foreign exchange reserve accumulation: A theory and some international evidence. Asian Development Bank Institute. https://bit.ly/38T8cgn

Giuliano, P., \& Ruiz-Arranz, M. (2009). Remittances, financial development, and growth. Journal of Development Economics, 90(1), 144-152. https://bit.ly/3sCGBrl

Gould, E. R. (2003). Money talks: Supplementary financiers and international monetary fund conditionality. International Organization, 57(3), 551-586. https://doi.org/10.1017/S0020818303573039

Granger, C. W. (1988). Some recent development in a concept of causality. Journal of Econometrics, 39(1-2), 199-211. https://doi.org/10.1016/0304-4076(88)90045-0

Greenslade, J. V., Hall, S. G., \& Henry, S. B. (2002). On the identification of cointegrated systems in small samples: a modelling strategy with an application to UK wages and prices. Journal of Economic Dynamics and Control, 26(9-10), 1517-1537. https://bit.ly/3qvioNi

International Monetary Fund Monetary. (2000). Annual Report on Exchange Arrangements and Exchange Restrictions 2000. Author.

Johansen, S. (1995). Likelihood-based inference in cointegrated vector autoregressive models. Oxford University Press. https://doi.org/10.1093/0198774508.001.0001

Kargbo, P. M. (2012). Impact of foreign aid on economic growth in Sierra Leone: Empirical Analysis. WIDER Working Paper. https://bit.ly/3nPBwIR

Kashif, M., Sridharan, P., \& Thiyagarajan, S. (2017). Impact of economic growth on international reserve holdings in Brazil. Brazilian Journal of Political Economy, 37(3), 605-614. https://doi.org/10.1590/010131572017v37n03a08

Krugman, P. R. (1984). The international role of the dollar: Theory and prospect. In Exchange rate theory and practice (pp. 261-278). University of Chicago press. https://bit.ly/3nRlugs

Kruskovic, B. D., \& Maricic, T. (2015). Empirical analysis of the impact of foreign exchange reserves to economic growth in emerging economics. Applied Economics and Finance, 2(1), 102-109. https://bit.ly/2XMiZlY

Lin, M. Y. (2011). Foreign reserves and economic growth: Granger causality analysis with panel data. Economics Bulletin, 31(2), 1563-1575.

Lubambu, K. M. K. (2014). The impacts of remittances on developing countries. European Parliament. https:// bit.ly/3nW6YVL

Lütkepohl, H., \& Krätzig, M. (Eds.). (2004). Applied time series econometrics. Cambridge university press.

Majagaiya, K. P. (2010). A time series analysis of foreign direct investment and economic growth: A case study of Nepal. International Journal of Business and Management, 2(2), 144-148. https://bit.ly/3bRELgm

McKinnon, R. I. (1973). Money and capital in economic development. The Brooking Institute.

Ministry of Finance. (2014). Nepal growth diagnostic. Ministry of Finance. https://bit.ly/2Ne9om2

Mohanty, M. S., \& Turner, P. (2006). Foreign exchange reserve accumulation in emerging markets: what are the domestic implications?. https://bit.ly/367gclT

Nathaniel, O. O., \& Oladiran, A. T. (2018). Foreign exchange reserve accumulation and

Nepal Rastra Bank (2016). Saving and investment pattern of remittance receiving households. Research Department. 
Nepal Rastra Bank (2019). A survey report on foreign direct investment in Nepal. Research Department. https://bit.ly/2M2Ya2V

Papanek, G. F. (1973). Aid, foreign private investment, savings, and growth in less developed countries. Journal of Political Economy, 81(1), 120-130. http://dx.doi.org/10.1086/260009

Park, D., \& Estrada, G. B. (2009). Are developing Asia's foreign exchange reserves excessive? An empirical examination. Asian Development Bank. https://bit.ly/3qvKixq

Polterovich, V., \& Popov, V. (2003). Accumulation of foreign exchange reserves and long term growth. https:// bit.ly/3bLwACk

Prabheesh, K.P., Malathy, D., \& Madhumathi, R. (2007). Demand for foreign exchange reserves in India: A cointegration approach. University Library of Munich. https://bit.ly/3oTdv4Y

Prasad, E. S., Rajan, R. G., \& Subramanian, A. (2007). Foreign capital and economic growth. National Bureau of Economic Research. https://bit.ly/39E69vL

Ray, S. (2012). Impact of foreign direct investment on economic growth in India: A cointegration analysis. Advances in Information Technology and Management, 2(1), 187-201. https://bit.ly/3sBff56

Regmi, U. R. (2009). Foreign aid and economic growth in Nepal: An application of cointegration and error correction modeling, The Economic Journal of Nepal, 32(2) 110-119. http://dx.doi.org/10.1353/ jda.0.0026

Rodrik, D. (2008). One economics, many recipes: Globalization, institutions, and economic growth. Princeton University Press. https://bit.ly/2LXsOLo

Senhadji, A. (1998). Time-series estimation of structural import demand equations: A cross-country analysis. IMF Economic Review, 45(2), 236-268. https://doi.org/10.2307/3867390

Uprety, D. (2017). The impact of remittances on economic growth in Nepal. Journal of Development Innovations, 1(1), 114-134. https://bit.ly/2N3UbUn

Weintraub, S. (1965). The foreign-exchange gap of the developing countries. Department of Economics, Princeton University. https://bit.ly/35Pz7HE

World Bank. (1997). World development indicators. Oxford University Press. 